УДК 8

DOI $10.21661 / \mathrm{r}-469008$

\title{
М.А. Арямнова
}

\section{ТЕКСТ КАК ЕДИНИЦА РЕЧЕВОЙ КОММУНИКАЦИИ}

Аннотация: в работе представлены проблемы понимания научных текстов с психологической и лингвистической точек зрения. Статья отражает характерные черты различных видов текстов, в том числе специиализированных. В различных отраслях науки есть огромное количество информации, наша задача - иметь возможности добыть эту информацию из разных источников. Необходимость извлечения информации достаточно насущуна. Поэтому проблема лёгкости понимания научных текстов и специиальных текстов, способов ее обеспечения является краеугольным камнем в обучении инженеров.

Ключевые слова: тексты, типь чтения, терминология, ключевые слова, основные знания, опыт, трудность понимания, специальные тексты, научные текстыл.

\section{M.A. Aryamnova}

\section{A TEXT AS A UNIT OF VERBAL COMMUNICATION}

Abstract: the article presents the problems of understanding scientific texts from psychological and linguistic points of view. It depicts characteristic features of different kinds of texts including texts for specific purposes. There is a great amount of information in the different fields of science, our task is to hare possibilities to get it from different sources. Necessity of information extraction is rather urgent. That's why the problem of easy and proper understanding of scientific texts, and texts for specific purposes, ways of its provision are keystones in engineers 'training.

Keywords: texts, types of reading, terminology, key words, basic knowledge, experience, difficulty of understanding, texts for specific purposes, scientific texts. 
Текст, будучи набором последовательных предложений, характеризуется логической когерентностью, смысловой завершенностью, и лексико-грамматической связанностью. Извлечение информации из текста осуществляется на нескольких уровнях: на лексическом уровне - с помощью специально отработанных лексических единиц. На синтаксическом уровне - это длина предложений: в научном тексте она в 1.7 раз больше чем в художественном. На стилистическом уровне - это термины, просторечия, сленги и т. д. - сигналы принадлежности текста к той или иной сфере.

Особой характеристикой текста являются ключевые слова, которые являются связанными звеньями текста, а также достаточно высокая частотность их употребления. Ключевые слова играют важную роль в понимании текста. Однако, проблема понимания научного текста всегда актуальна.

Хотя научный текст изобилует однозначными словами, он логичен, строг в формулировках и не столько богат средствами выражения, как художественный, научный текст затруднителен в понимании. Причинами затруднений являются терминологическая насыщенность, информационная глубина, с одной стороны, и разные уровни в данной области у адресата и адресанта. У адресата малая осведомленность о предмете описываемого и нет возможности установить контекстуальные экстралингвистические связи лексических единиц. Чтобы оказаться среди «понимающих» необходимо владеть хотя бы частичными знаниями и близким общекультурным фоном.

Знания в предметной области являются залогом лучшего понимания текста, адресат должен быть осведомлен о значении ключевых слов и связанных с ними предметных контекстах. Это качество красноречиво демонстрируют студенты, которые значительно легче начинают понимать тексты, базирующиеся на прослушанном материале специальных учебных дисциплин. Действительно, процесс понимания становится быстрым, простым и понятным.

С психологической точки зрения чтение и понимание текста представляет собой сложную аналитико-синтетическую деятельность, складывающуюся из восприятия и понимания текста. Зрелое же чтение характеризуется слиянием 
этих двух процессов и концентрацией внимания на смысловой стороне содержания. Психологическая трактовка чтения подчеркивает, что для понимания иноязычного текста требуется владение набором фонетических, лексических и грамматических информативных признаков, которые делают процесс опознавания быстрее. Если этот набор не освоен, то перцептивные действия читающего принимают развернутые формы и выполняются с большими интервалами, затрудняющими или нарушающими процесс извлечения информации.

В речевых механизмах чтения большую роль играют речевой слух, прогнозирование и память. Речевой слух определяется особенностью звукобуквенной системы печатного текста, ассоциациями которых должен владеть читающий. Прогнозирование определяет успешность восприятия и понимание в любых видах чтения. Условием прогнозирования являются наличие и систематизация прошлого опыта. Чем опытнее читающий, тем точнее его антипация содержания.

Понимание содержания происходит на основе ряда сложных логических операций результатом которых являются установление связей в тексте и переход от развернутых слов к смысловым верхам.

В зарубежной методике предлагается свыше 30 видов чтения, некоторые из которых очень близки по содержанию - так, просмотровое чтение классифицируют на такие виды, как: общий обзор (skimming), предварительный обзор (preview), повторный обзор (review), просмотр (scanning).

Для сравнения Г.Э. Пифо выделил 8 видов чтения: беглое чтение, поисковое, аналитическое, критическое чтение, сравнительное и интерпретирующее чтение, оценивающее чтение и чтение как источник получения и расширения языковых средств.

Отечественный методист С.К. Фоломкина определяет виды чтения как «набор операций, обусловленных целью чтения и характеризующихся специфическим сочетанием приемов смысловой и перцептивной переработки материала, воспринимаемого зрительно». Согласно классификации С. К. Фоломкиной виды чтения делятся на просмотр, ознакомление, поиск информации и детально изучению. 
При изучении научно-популярных и научных текстов студентами мы используем данные виды чтения в зависимости от целеполагания. Вообще, в научно-популярных текстах, статьях пропагандируют достижения науки и техники. Эти тексты адресованы массовому читателю, поэтому материал текстов излагается в доступной форме. В них используется незначительное количество цифровых данных, диаграмм, графиков и терминов. Тексты научно-популярного стиля лишены подтекстов, экспрессии, сложного синтаксиса в раскрытии содержания. Заголовок обычно информативен, введение содержит ознакомление с темой или историю вопроса. Тексты этого стиля могут быть использованы при обучении всем видам чтения. Что касается текстов научного стиля они фиксируют и хранят знания из разных областей науки, либо они представляют обучение, что делает возможным дальнейшие развитие науки.

В вузах тексты данного стиля используются на профильно ориентированных факультетах в соответствии с будущей профессией студентов при изучающем и поисковом чтении. Научный текст характеризуется подчеркнутой логичностью, многократными повторами с дополнительной аргументацией, сложным синтаксисом и многообразием профессионально ориентированной тематики.

\section{Список литературы}

1. Гальперин И.Р. Текст как объект лингвистических исследований. - М., 1981. $-230 \mathrm{c}$.

2. Гальскова Н.Д. Теория обучения иностранным языка: Лингводидактика и методика / Н.Д. Гальскова, Н.И. Гез.- М.: Издательский центр «Академия», 2004. -336 c.

3. Образовательный подходы в обучении иностранным языкам в инновационном контексте Сибирского региона: Коллективная монография / Под ред. Г.А. Ферапонтова. - Новосибирск: Изд-во НГПУ, 2016. - 114 с.

4. Шехтман Н.А. Понимание речевого произведения и гипертекст: Учебное пособие / Н.А. Шехтман. - М.: Высшая школа, 2009. - 159 с.

\section{References}

1. Gal'perin, I.R. (1981). Tekst kak obekt lingvisticheskikh issledovanii, 230. M. 
2. Gal'skova, N.D., \& Gez, N.I. (2004). Teoriia obucheniia inostrannym iazyka: Lingvodidaktika i metodika, 336. M.: Izdatel'skii tsentr "Akademiia".

3. (2016). Obrazovatel'nyi podkhody v obuchenii inostrannym iazykam v innovatsionnom kontekste Sibirskogo regiona: Kollektivnaia monografiia, 114. Novosibirsk: Izd-vo NGPU.

4. Shekhtman, N.A. (2009). Ponimanie rechevogo proizvedeniia i gipertekst, 159. M.: Vysshaia shkola.

Арямнова Марина Анатольевна - соискатель, старший преподаватель кафедры иностранных языков для инженерных направлений Института филологии и языковой коммуникации ФГАОУ ВО «Сибирский федеральный университет», Россия, Красноярск.

Aryamnova Marina Anatolievna - senior instructor of the department of Foreign language for engineering specialities, Institute of philology and verbal communication of Siberian Federal University, Russia, Krasnoyarsk. 